\title{
Sometimes Eearly Learned Instances Interfere with the Implementation of Rules: The Case of Nominal Number Agreement
}

M.-P. Cousin, P. Largy and M. Fayol

\section{OpenEdition}

\section{Journals}

Electronic version

URL: http://journals.openedition.org/cpl/206

DOI: $10.4000 / \mathrm{cpl} .206$

ISSN: $1379-6100$

Publisher

Centre PsyCLÉ

\section{Printed version}

Date of publication: 1 August 2002

\section{Electronic reference}

M.-P. Cousin, P. Largy and M. Fayol, « Sometimes Eearly Learned Instances Interfere with the Implementation of Rules: The Case of Nominal Number Agreement », Current psychology letters [Online], 2002/2, 8 | 2002, Online since 05 September 2003, connection on 08 September 2020. URL : http://journals.openedition.org/cpl/206 ; DOI : https://doi.org/10.4000/cpl.206

This text was automatically generated on 8 September 2020

(c) All rights reserved 
Sometimes Eearly Learned Instances Interfere with the Implementation of Rules: The Case of Nominal Number Agreement M.-P. Cousin, P. Largy and M. Fayol 